\title{
Instrumen Kepuasan Mahasiswa Universitas Swasta Dengan Menggunakan Pemodelan Rasch
}

\author{
Rais Hidayat \\ Universitas Pakuan \\ rais72rais@gmail.com \\ Eka Suhardi \\ Universitas Pakuan \\ ekasuhardi@gmail.com \\ Yuyun Elizabeth Patras \\ Universitas Pakuan \\ yuyunelizabethpatras@gmail.com
}

\begin{abstract}
Student satisfaction at a university could predict the continuity of the university. Therefore understanding and improving student satisfaction needs to be done. This study provides an alternative model of student satisfaction instruments at private universities. The research methodology consists of a series of literature reviews, interviews, expert validation and testing the validity of the instrument using the Rasch model. The respondents of this study were 543 students from 6 faculties in a private university. Research findings include: (1) student satisfaction instrument models; (2) items that are difficult to approve; and (3) items perceived differently based on respondents' demographics. This research has implications for the management of private universities to improve some domains of student satisfaction.
\end{abstract}

Keywords: Student Satisfaction, Rasch Model, Private University

\section{Article Info}

Received date: 20 Oktober $2019 \quad$ Revised date: 18 Desember $2019 \quad$ Accepted date: 20 Desember 2019

\section{PENDAHULUAN}

Upaya mengembangkan sumber daya manusia dapat dilakukan dengan pendidikan, termasuk pendidikan tinggi di sebuah universitas.Agar mampu menghasilkan sumberdaya manusia berkualitas maka universitasharus mengembangkan sistem pendidikan yang berkualitas (D Napitupulu, R Rahim, D Abdullah, MI Setiawan, LA Abdillah, AS Ahmar, J Simarmata, R Hidayat,
H Nurdiyanto, 2018). Salah satu upaya mewujudkan system tersebut dengan meningkatkan kepuasan para mahasiswanya(Muhammad, Kakakhel, Baloch, \& Ali, 2018).

Kmampuan memberikan kepuasan kepada mahasiswa merupakan salah satu indikator kualitative yang sangat penting (Khosravi, Poushaneh, Roozegar, \& Sohrabifard, 2013), kepuasan mahasiswa 
menjadi kunci bagi sebuah universitas dalam meraih ranking (Nurunnabi \& Abdelhadi, 2019). Mahasiswa yang lulus dengan perasaan puas kepada universitasnya akan membantu universitas dalam meraih pasar yang lebih luas (Lenton, 2015). Oleh karena itu focus kepada mahasiswa, termasuk pada kepuasan mereka merupakan kunci keberhasilan yang menentukan bagi sebuah universitas(Elliott, 2003).

Diperlukan sebuah instrument untuk dapat menggali kepuasaan mahasiswa serta factor-faktor yang berpengaruh kepada kepuasan mahasiswa (Siming, Gao, \& Xu, 2015). Sejumlah penelitian telah dilakukan antara lain penelitian kepuasan mahasiswa terhadap mata kuliah dan pengajarannya (Huybers, Louviere, \& Islam, 2015), hubungan social dengan teman dan dosen (Bakadorova \& Raufelder, 2018) dan kepuasaan ketika menyelesaikan sarjana dan pengaruhnya di tempat kerja (Moro-egido \& Panadés, 2014).

Halbaru dalam penelitian ini yaitumenggunakan metode penelitia melalui kajian literature, wawancara, pendapat ahli dan analisisinstrument menggunakan pemodelan Rasch. Adapun pertanyaan penelitian ini sebagai berikut: (1) Manakah aitem-aitem instrument kepuasan mahasiswa yang valid; (2) manakah aitem yang sulit disetujui; dan (3) manakah aitem yang dipersepsikan berbeda dari sudut padangdemografi responden.

Kepuasan mahasiswa mengacu kepada akumulasi persepsi dan sikap mahasiswa yang berasal dari gabungan manfaat yang mereka terima(Alemu \& Cordier, 2017), berupa hasil evaluasi mahasiswa terhadap proses pembelajaran (Huybers et al., 2015), hubungan mahasiswa dan dosen, pengalaman belajar, dukungan kepada mahasiswa, fasilitas dan jasa yang diberikan, cara dosen dalam mempersiapkan pembelajaran(Siming et al., 2015), cara dosen mengajar (Garnjost \& Lawter, 2019) dan cara dosen mengevaluasi pembelajaran(Elliott, 2003).
Indikator kepuasan mahasiswa meliputi kepuasan pada pengalaman belajar, keterlibatan dalam pembelajaran,kualitas pengajaran, sumber belajar, dukungan, dan pengembangan keterampilan(Li \& Carroll, 2017), penilaian dan feedback, managemen organisasi(Nurunnabi \& Abdelhadi, 2019), semua bentuk jasa yang diberikan universitas (El-said \& Ahmed, 2015), hubungan dengan teman, kehidupan social, dan kebebasan (Bakadorova \& Raufelder, 2018), kepuasan pada hasil berlajar, lingkungan belajar (Topala \& Tomozii, 2014), academic, programme, reputation, non-academic, dan akses (Muhammad et al., 2018), academic advising effectiveness, campus support services, campus life, responsiveness to diverse populations, safety and security, campus climate, financial aid effectiveness (Khosravi et al., 2013).

\section{Pemodelan Rasch}

Rasch Model merupakan salah satu pendekatan statistik yang dapat dipergunakan dalam mengukur kinerja, sikap, dan persepsi. Model ini dinamakan berdasarkan nama penemunya tahun 1960, Georg Rasch yang berkebangsaan Denmark(Tesio, 2003). Pemodelan Rasch banyak digunakan dalam ilmu social (Bond \& Fox, 2007), penggunaannya sangat direkomendasik untuk meningkatkan kualitas pengukurandalam penelitian qualitative maupun quantitative(Stef van Buuren, 2015).

Pemodelan Rasch mengacu pada item response theory dengan memeriksa kualitas penilaian skala psikometrik dan menginformasikannya dengan lebih baik (ZileTamsen, 2017). Pemodelan Rasch sangat berguna bagi penelitian, termasuk untuk penelitian bidang pendidikan, misalnyauntuk membuat instrumen yang dapat mengukur kondusifitas dalam pembelajaran (NGUYEN THANH DONG, 2014).

Kelebihan dari pemodelan Rasch antara dapat menjelaskan aitemdan person(Carvalho, Primi, \& Meyer, 2012). Pemodelan Rasch dapat 
mengukur kemampuan dan kesulitan aitem( $\mathrm{Wu}$ \& Adams, 2007). Pemodelan Rasch mampu mengatasi masalah integritas data melalui akomodasi transformasi logit dengan menerapkan logaritma pada rasio ganjil dari data mentah yang diperoleh dari responden (Linacre, 2010).

\section{METODE PENELITIAN}

Penelitian ini menggunakan pendekatan pengembangan yang bertujuan untuk membuat instrumen penelitian kepuasan mahasiswa di universitas swasta sekaligus mendeskripsikan persepsi responden pada butir instrumen berdasarkan demografi responden meliputi jenis kelamin, status sekolah, fakultas dan alasan masuk universitas swasta. Kemudian peneliti membahas beberapa temuan penting untuk memperbaiki kepuasan mahasiswa.Penelitian dilaksanakan di Universitas Pakuan, Jawa Barat. Jumlah responden sebanyak 543mahasiswa.

Dalam penelitian ini kepuasan mahasiswa diartikan sebagai persepsi mahasiswa atas pengalaman mereka selama belajar di universitas swasta yang sumber datanya diperoleh dari instrument berupa angket yang diisi oleh mahasiswa terhadap 10 pernyataan sebagai berikut: (ST1) Saya puas dalam melaksanakan tugas sebagai mahasiswa; (ST2) Saya puas dengan hasil belajar yang dicapai; (ST3) Saya puas dengan pengalaman belajar yang saya dapatkan; (ST4) Saya puas dengan karakter sesama mahasiswa; (ST5) Saya puas dengan kondisi lingkungan belajar; (ST6) Saya puas dengan interaksi sesama mahasiswa; (ST7) Saya puas dengan layanan tata usaha (administrasi); (ST8) Saya puas dengan layanan tenaga pelaksana (tenaga kebersihan); (ST9) Saya bangga menjadi mahasiswa; (ST10) Saya menceritakan hal-hal baik tentang Universitas kepada orang lain.

Tahapan penelitan antara lain: (1) melakukan kajian literatur untuk mendapatkan beberapa indikator dalam mengukur kepuasan mahasiswa, (2) wawancara mahasiswa, (3) Meminta pendapat ahli atas aitem, dan (3) melakukan pengujian instrumen menggunakan Rach Model. Jenis skala yang digunakan adalah skala penilaian Likert dengan lima pilihan peringkat (Hendriks et al., 2012). Proses pengolahan data dimulai dengan input data dari kuesioner yang berbentuk skala ordinal kemudian dikonversi ke skala interval menggunakan pemodelan Rasch melalui perangkat lunak Winsteps versi 3.73.

Pengujian dilakukan pada 3 hal, yaitu:

(1) Pengujian validitas aitem dengan menggunakan tes item fit order; (2) Pengujian butir instrumen yang paling sulit disetujui disetujui menggunakan tes item measure; dan (3) Pengujian persepsi atau bias berdasarkan demografi dengan menggunakan tes Differential Item Functional (DIF) plot(Bambang Sumintono, 2014). Kriteria adanya perbedaan persepsi dilihat dari garis nol, di mana jika nilai persepsi orang berada di atas garis nol menunjukkan sulitmenyetujui pernyataan dan sebaliknya (Bambang Sumintono, 2015).

\section{HASIL DAN PEMBAHASAN}

Validity. Skor INFIT MNSQ untuk butir yang valid seperti pada tabel 1 adalah sebesar 1.14 atau $(0.99+0.15)$. Berdasarkan hasil uji tersebut maka terdapat 2 aitem yaitu ST7, ST8yang harus didrop karena skornya lebih besar dari 1.14.Selanjutnya analisis dalam penelitian ini hanya menggunakan aitem yang valid.

Berdasarkan temuan ini maka ke 8 (delapan) aitem kepuasan mahasiswadalam instrument ini menjadi sebuah model instrument bagi penelitian. Dengan kata lain instrument ST4, ST2, ST10, ST5, ST6, ST1, ST9, dan ST3 dapat digunakan dalam penelitian kepuasan mahasiswa. Pengujian instrumen sangat penting dalam sebuah penelitian (Takaki, Taniguchi, \& Fujii, 2014).Hasil pengujian ini merupakan bagian pengujian 
validitas instrument pada kelompok sampel yang merupakan suatu keharusan(Brinkman, 2009). Adanya beberapa aitem yang didrop pada sebuah instrument penelitian yang menggunakan skala Likert merupakan hal biasa(Brinkman, 2009). Keberhasilan pengujian ini dengan Rasch Model menunjukkan bahwa pemodelan Rasch dapat menjadi alternatif bagi pengujian validitas instrumen.Kelebihan dari pemodelan Rasch adalah dapat menjelaskan aitem (butir) dan responden dari sisi demografinya(Carvalho et al., 2012), pemodelan Rasch dapat membantu untuk mengatasi pengukuran aitem (butir) dengan cara yang benar(Wu \& Adams, 2007).

Tabel 1 Uji Validitas Aitem Instrumen Kepuasan Mahasiswa

\begin{tabular}{|c|c|c|c|c|c|c|c|c|c|c|c|c|c|}
\hline \multirow{2}{*}{$\begin{array}{l}\text { ENTRY } \\
\text { NUMBER }\end{array}$} & \multirow{2}{*}{$\begin{array}{l}\text { TOTAL } \\
\text { SCORE }\end{array}$} & \multirow{2}{*}{$\begin{array}{l}\text { TOTAL } \\
\text { COUNT }\end{array}$} & \multirow[b]{2}{*}{ MEASURE } & \multirow{2}{*}{$\begin{array}{l}\text { MODEL } \\
\text { S.E. }\end{array}$} & \multicolumn{2}{|c|}{ INFIT } & \multicolumn{2}{|c|}{ OUTFIT } & \multicolumn{2}{|c|}{ |PT -MEASURE } & \multirow{2}{*}{$\begin{array}{r}\text { EXACT } \\
\text { OBS\% }\end{array}$} & \multirow{2}{*}{$\begin{array}{r}\text { MATCH| } \\
\text { EXP\%| }\end{array}$} & \multirow[b]{2}{*}{ Item } \\
\hline & & & & & MNSQ & ZSTD| & MNSQ & ZSTD|CO & RR. & EXP. & & & \\
\hline \multicolumn{14}{|c|}{ 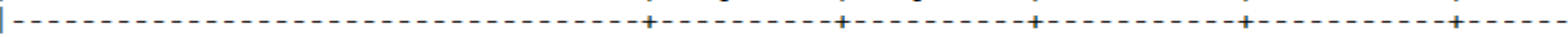 } \\
\hline 7 & 1952 & 543 & .77 & $.07 \mid$ & 1.24 & 3.2 & 1.27 & $3.4 \mid \mathrm{A}$ & .74 & $.77 \mid$ & 67.6 & 63.31 & ST7 \\
\hline 8 & 2051 & 543 & .19 & $.08 \mid$ & 1.20 & $2.6 \mid$ & 1.16 & $2.0 \mid \mathrm{B}$ & .75 & $.76 \mid$ & 68.9 & $66.6 \mid$ & ST8 \\
\hline 4 & 2038 & 543 & .27 & $.08 \mid$ & 1.14 & $1.9 \mid$ & 1.14 & $1.7 \mid \mathrm{C}$ & .73 & .76 & 67.6 & $66.4 \mid$ & ST4 \\
\hline 2 & 2054 & 543 & .17 & .08 & 1.06 & .81 & 1.01 & $.2 \mid \mathrm{D}$ & .75 & $.76 \mid$ & 68.4 & $66.7 \mid$ & ST2 \\
\hline 10 & 2182 & 543 & -.71 & .09 & 1.04 & $.6 \mid$ & 1.00 & $.0 \mid \mathrm{E}$ & .74 & $.74 \mid$ & 74.4 & $70.1 \mid$ & ST10 \\
\hline 5 & 1973 & 543 & .65 & $.07 \mid$ & .86 & $-2.0 \mid$ & .97 & $-.3 \mid \mathrm{e}$ & .80 & .77 & 70.7 & $63.7 \mid$ & ST5 \\
\hline 6 & 2076 & 543 & .03 & .08 & .92 & -1.0 & .84 & $-2.1 \mid d$ & .75 & .76 & 72.1 & 67.51 & ST6 \\
\hline 1 & 2148 & 543 & -.46 & .08 & .87 & -1.8 & .89 & $-1.5 \mid c$ & .75 & .751 & 74.6 & $69.6 \mid$ & ST1 \\
\hline 9 & 2182 & 543 & -.71 & .091 & .81 & -2.7 & .75 & $-3.5 \mid b$ & .79 & $.74 \mid$ & 77.9 & $1 \mid$ & ST9 \\
\hline 3 & 2112 & 543 & -.21 & .081 & .80 & -2.8 & .77 & $-3.1 \mid a$ & .80 & .751 & 72.7 & $68.7 \mid$ & ST3 \\
\hline \multicolumn{14}{|c|}{ 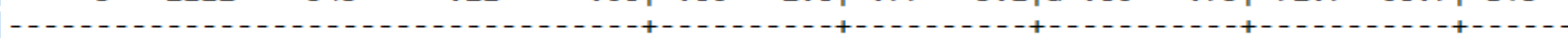 } \\
\hline MEAN & 2076.8 & 543.0 & .00 & $.08 \mid$ & .99 & $-.1 \mid$ & .98 & $-.3 \mid$ & & & 71.5 & $67.3 \mid$ & \\
\hline S.D. & 75.8 & .0 & .49 & .00 & .15 & 2.11 & .16 & $2.2 \mid$ & & & 3.3 & $2.3 \mid$ & \\
\hline
\end{tabular}

Keterangan tabel 1. ST = Student Satisfaction

Aitem paling sulit. Hasil pengujian menggunakan item measure sebagaimana tertera pada tabel 2 menunjukkan bahwa terdapa 5 item yang sulit disetuji responden, berdasarkan ranking yaitu: ST5 (kondisi lingkungan), ST4 (karakter sesame mahasiswa), ST2 (hasil belajar yang dicapai), ST6 (interaksi), dan ST3 (pengalaman belajar).

Arti dari tingkat kesulitan persetujuan ini bahwa manajemen universitas swasta harus memperbaiki 5 domain kepuasan mahasiswa yaitu: (1) Kondisi lingkungan harus mendukung proses pembelajaran (Papachristos, Vrellis, Natsis, \& Mikropoulos, 2014); (2)
Diperlukan pendidikan karakter pada mahasiswa(Yanikoski, 2004), karakter yang yang kuat dibutuhkan sebagai bekal dalam meraih kesuksesan (Annette, 2005); (3) Diperlukan peningkatan materi-materi perkuliahan (Ellis \& Goodyear, 2016)agar mahasiswa terbekali ilmu pengetahuan sebelum masuk dunia kerja dan hidup di masyarakat, (4) Diperlukan perbaikan interaksi antara dosen dengan mahasiswa dan mahasiswa dengan mahasiswa(Bakadorova \& Raufelder, 2018), dan (5) Diperlukan peningkatan pengalaman belajar untuk mahasiswa, baik teori maupun praktik (Williams, 2012). 
Tabel 2 Rangking Tingkat Persetujuan Responden pada Aitem

\begin{tabular}{|c|c|c|c|c|c|c|c|c|c|c|c|c|c|}
\hline \multirow{2}{*}{$\begin{array}{l}\text { | ENTRY } \\
\text { | NUMBER }\end{array}$} & TOTAL & TOTAL & & MODEL | & \multicolumn{2}{|c|}{ INFIT } & \multicolumn{2}{|c|}{ OUTFIT } & \multicolumn{2}{|c|}{ |PT-MEASURE } & \multirow{2}{*}{$\begin{array}{r}\text { EXACT } \\
\text { OBS\% }\end{array}$} & \multirow{2}{*}{$\begin{array}{r}\text { MATCH | } \\
\text { EXP\% }\end{array}$} & \multirow[b]{2}{*}{ Item } \\
\hline & SCORE & COUNT & MEASURE & S.E. & MNSQ & ZSTDI & MNSQ & ZSTD & |CORR. & EXP. I & & & \\
\hline & & & & & & & & & & & & & \\
\hline 7 & 1952 & 543 & .77 & $.07 \mid$ & 1.24 & 3.21 & 11.27 & 3.4 & .74 & .77| & 67.6 & 63.31 & ST7 \\
\hline 5 & 1973 & 543 & .65 & $.07 \mid$ & .86 & -2.0 & .97 & -.3 & .80 & $.77 \mid$ & 70.7 & $63.7 \mid$ & ST5 \\
\hline 4 & 2038 & 543 & .27 & .08 & 1.14 & 1.91 & 1.14 & 1.7 & .73 & .76 & 67.6 & $66.4 \mid$ & ST4 \\
\hline 8 & 2051 & 543 & .19 & .081 & 1.20 & $2.6 i$ & 1.16 & 2.0 & .75 & $.76 \mid$ & 68.9 & $66.6 i$ & ST8 \\
\hline 2 & 2054 & 543 & .17 & .08 & 1.06 & .81 & 1.01 & .2 & .75 & $.76 \mid$ & 68.4 & $66.7 \mid$ & ST2 \\
\hline 6 & 2076 & 543 & .03 & .08 & .92 & $-1.0 \mid$ & .84 & -2.1 & .75 & $.76 \mid$ & 72.1 & $67.5 i$ & ST6 \\
\hline 3 & 2112 & 543 & -.21 & .081 & .80 & -2.8 & .77 & -3.1 & .80 & $.75 \mid$ & 72.7 & $68.7 \mid$ & ST3 \\
\hline 1 & 2148 & 543 & -.46 & .081 & .87 & -1.8 & .89 & -1.5 & .75 & $.75 \mid$ & 74.6 & $69.6 \mid$ & ST1 \\
\hline 9 & 2182 & 543 & -.71 & $.09 \mid$ & .81 & -2.7 & .75 & -3.5 & .79 & $.74 \mid$ & 77.9 & 70.11 & ST9 \\
\hline 10 & 2182 & 543 & -.71 & $.09 \mid$ & 1.04 & $.6 \mid$ & 1.00 & .0 & .74 & $.74 \mid$ & 74.4 & $70.1 \mid$ & ST10 \\
\hline & $----\cdot$ & & - & ---7 & & - & - & - & & ---+ & --- & -- & \\
\hline MEAN & 2076.8 & 543.0 & .00 & $.08 \mid$ & .99 & -.11 & .98 & -.3 & & & 71.5 & 67.31 & \\
\hline S.D. & 75.8 & .0 & .49 & .001 & .15 & 2.11 & .16 & 2.2 & & | & 3.3 & 2.31 & \\
\hline
\end{tabular}

Kepuasan mahasiswa berdasar jenis kelamin. Terdapat perbedaan persepsi antara mahasiswa laki-laki (garis 1)dengan mahasiswa perempuan (garis 2) pada aitem ST3 (pengalaman belajar), ST4 (karakter sesama mahasiswa), dan ST6 (interaksi) seperti pada gambar 1. Hal tersebutmenunjukkan bahwa responden laki-laki lebih menuntut kepuasan pengalaman belajar yang tinggi dibanding perempuan. Sementara itu responden perempuan lebih menuntut kepuasan yang lebih tinggi atas karakter dan interaksi di dalam kampus(Kyoung \& Knight, 2016). Semua harapan mahasiswa laki-laki dan perempuan harus diwujudkan karena akan menyebabkan kesetiaan pelanggan (Oriade \& Scho, 2019)

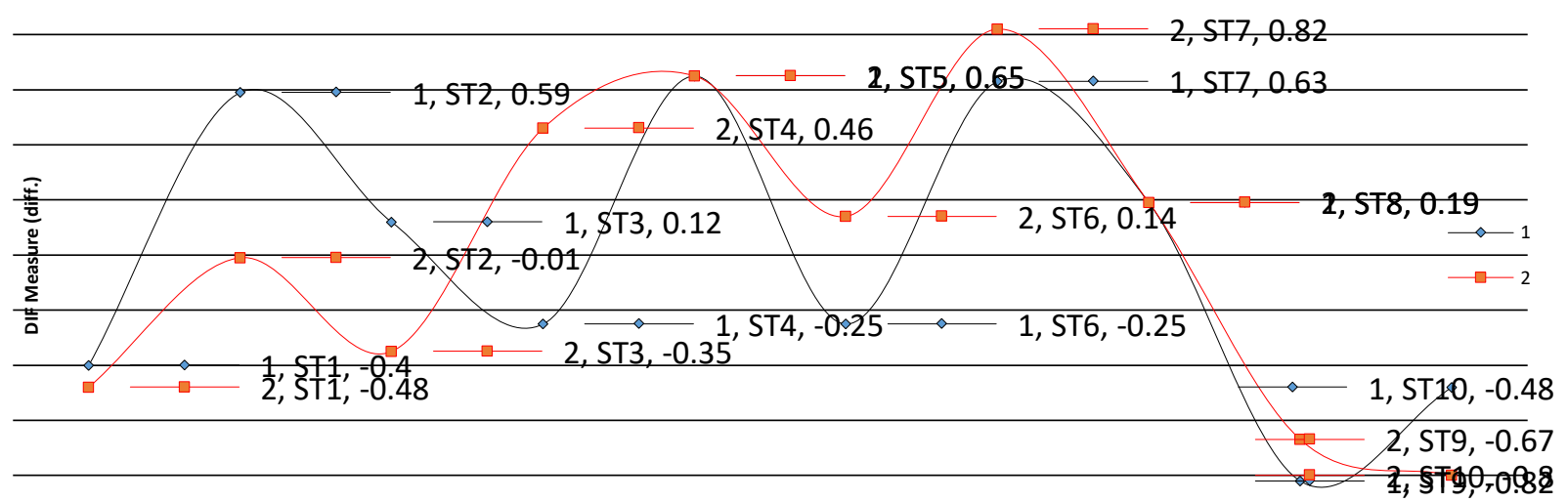

Gambar 1 Persepsi Mahasiswa Pada Aitem Berdasarkan Jenis Kelamin

Keterangan gambar 1: 1 = mahasiswa laki-laki, 2 = mahasiswa perempuan

Kepuasan Mahasiswa Berdasar Status Sekolah. Terdapat perbedaan persepsi antara responden yang berasal dari sekolah negeri (garis 1) dengan responden yang berasal dari sekolah swasta (garis 2) pada ST6 (interaksi). Fakta ini berarti bahwa responden yang terbiasa belajar di sekolah negeri merasa "ada suasana berbeda" dengan belajar di suanasa kampus swasta(Boon, Shukur, \& Bassim, 2016). Suanana sekolah negeri umumnya inisiatif untuk belajar berasal dari siswa, namun belajar di kampus swasta harus ada inisiatif belajar yang lebih dari lingkungan kampus (Triventi \& Trivellato, 2012). 


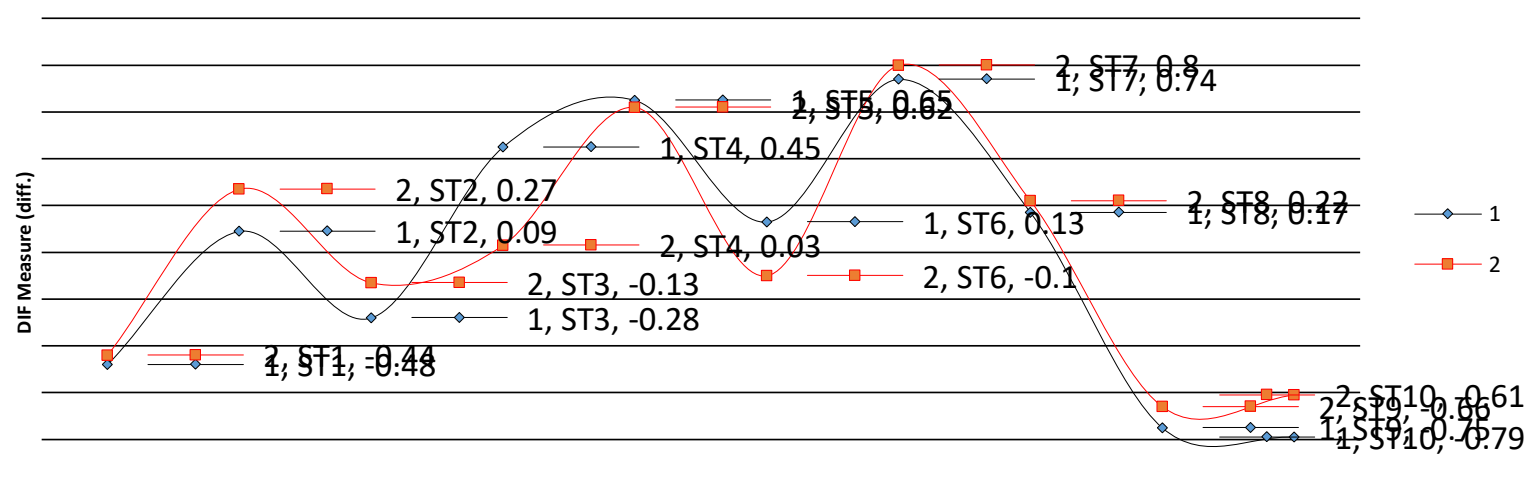

Gambar 2 Persepsi Mahasiswa Berdasarkan Latar Belakang Status Sekolah Menengah. Keterangan Gambar 2: 1 = sekolah meengah negeri, 2 = sekolah menengah swasta

Kepuasan mahasiswa berdasar dari fakultas Sosial dan Budaya (FISIB) fakultas. Terdapat perbedaan persepsi menuntut kepuasan lebih tinggi atas hasil responden berdasarkan fakultas khususnya belajar dan pengalaman belajar. Sementara itu pada aitem ST2 (Hasil Belajar), ST3 responden dari fakultas hukum (garis 5) (Pengalaman Belajar), dan ST4 (karakter menuntut kepuasan lebih tinggi mahasiswa), dimana mahasiswa yang berasal padalingkungan kampus.

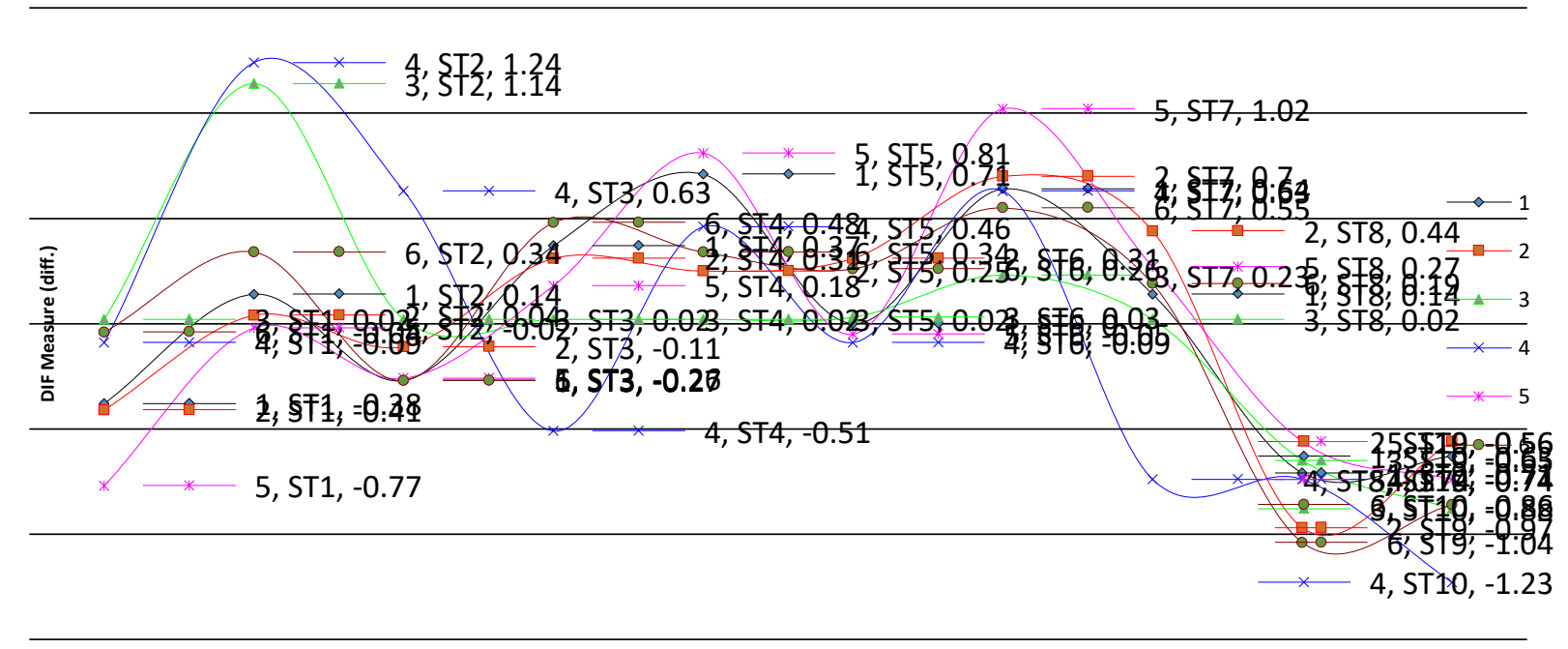

Gambar 3 Persepsi Mahasiswa Berdasar Fakultas

Keterangan Gambar $3: 1=$ MIPA, $2=$ FKIP, $3=$ FISIB, $4=$ FE , $5=$ FH, $6=$ FT .

\section{Kepuasan mahasiswa berdasarkan} Alasan Masuk Universitas.Terdapat perbedaan persepsi berdasarkan alasan responden masuk universitas khususnya pada aitem ST2 (hasil belajar), ST3 (pengalaman belajar), ST4 (karakter mahasiswa) dan ST6 (interaksi). Responden yang memiliki alasan masuk universitas karena mutu menuntut hasil belajar dan pengalaman yang paling tinggi (garis 6). Responden yang masuk universitas karena alasan teman menuntut karakter mahasiswa paling tinggi (garis 2). 


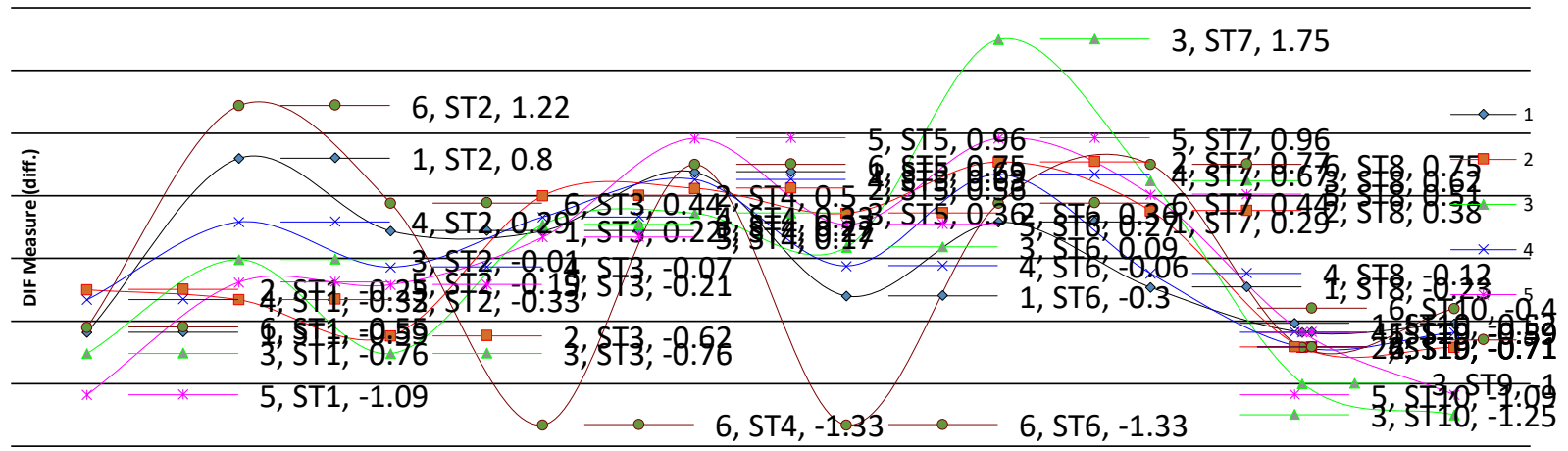

Gambar 3 Persepsi Mahasiswa Berdasar Alasan Masuk Universitas

Keterangan Gambar : 1 = Orang Tua, $2=$ Teman , $3=$ Promosi, $4=$ Fasilitas , $5=$ Lainnya, $6=$ Mutu Universitas.

\section{SIMPULAN}

Penelitian ini menemukan 8 dari 10 aitem yang dapat digunakan dalam penelitian kepuasan mahasiswa di universitas swasta. Instrument tersebut dikembangkan melalui proses penelitian yang dimulai dari kajian literatur, wawancara, validasi ahli dan uji validitas instrumen menggunakan pemodelan Rasch. Penggunaan analisis pemodelan Rasch menemukan terdapat aitem-aitem istrumen kepuasan mahasiswa yang sulit disetujui oleh mahasiswa berdasarkan demografi mahasiswa. Tingkat persetujuan tersebut bermakna bahwa manajemen universitas swasta harus meningkatkan kepuasan pada domain yang sulit disetujui mahasiswa. Implikasi penelitian ini yaitu diperlukan upaya peningkatan kepuasan mahasiswa di universitas swasta terhadap beberapa domain, yaitu: kondisi lingkungan, karakter mahasiswa, hasil belajar, interaksi, dan pengalaman belajar.

\section{DAFTAR PUSTAKA}

Alemu, A. M., \& Cordier, J. (2017). International Journal of Educational Development Factors in $\mathrm{fl}$ uencing international students satisfaction in Korean universities. International Journal of Educational Development, 57(December 2016), 54-64. https://doi.org/10.1016/j.ijedudev.2017. 08.006
Annette, J. (2005). Character, Civic Renewal annd Service Learning For Democratic Citizenship In Higher Education. British Journal of Educational Studies, 53(3), 326-340.

Bakadorova, O., \& Raufelder, D. (2018). The essential role of the teacher-student relationship in students, need satisfaction during adolescence. Journal of Applied Developmental Psychology, 58(August), https://doi.org/10.1016/j.appdev.2018.0 8.004

Bambang Sumintono, W. W. (2014). Aplikasi Model Rasch Untuk Penelitian IlmuIlmu Sosial. Cimahi: Trim Komunikata.

Bambang Sumintono, W. W. (2015). Aplikasi Pemodelan Rasch pada Asesment Pendidikan. Cimahi: Trim Komunikata.

Bond, T. G., \& Fox, C. M. (2007). Applying the Rasch Model: Fundamental Measurement in the Human Sciences Second Edition University of Toledo. New Jersey 07430: Lawrence Erlbaum Associates, Inc.

Boon, T., Shukur, M., \& Bassim, A. (2016). Evaluation of Service Quality of Private Higher Education using Service Improvement Matrix. Procedia - Social and Behavioral Sciences, 224(August 
2015),

$132-140$.

https://doi.org/10.1016/j.sbspro.2016.0

5.417

Brinkman, W.-P. (2009). Design of a Questionnaire Instrument. Handbook of Mobile Technology Research Methods, (December), 31-57.

Carvalho, L. D. F., Primi, R., \& Meyer, G. J. (2012). Application of the Rasch model in measuring personality disorders. Trends, 34(2), 101-109.

D Napitupulu, R Rahim, D Abdullah, MI Setiawan, LA Abdillah, AS Ahmar, J Simarmata, R Hidayat, H Nurdiyanto, A. P. (2018). Analysis of Student Satisfaction Toward Quality of Service Facility Analysis of Student Satisfaction Toward Quality of Service Facility. JIOP Conf. Series: Journal of Physics: Conf, (954).

El-said, O. A., \& Ahmed, E. (2015). Assessing university students ' satisfaction with on-campus cafeteria services. TMP, 16, 318-324.

https://doi.org/10.1016/j.tmp.2015.09.0 06

Elliott, K. M. (2003). Key Determinants Of Student Satisfaction. J. COLLEGE STUDENT RETENTION, 4(3), 271279.

Ellis, R. A., \& Goodyear, P. (2016). Models of learning space : integrating research on space, place and learning in higher education. Review OfEducation, 4(2), 149-191.

https://doi.org/10.1002/rev3.3056

Garnjost, P., \& Lawter, L. (2019). The International Journal of Undergraduates , satisfaction and perceptions of learning outcomes across teacher- and learner-focused pedagogies. The International Journal of Management
Education, $17(2)$ $267-275$. https://doi.org/10.1016/j.ijme.2019.03. 004

Hendriks, J., Fyfe, S., Styles, I., Skinner, S. R., Merriman, G., \& Hendriks, J. (2012). Scale construction utilising the Rasch unidimensional measurement model : A measurement of adolescent attitudes towards abortion. Australasian Medical Journal [AMJ 2012,5(5), 251-261.

Huybers, T., Louviere, J., \& Islam, T. (2015). The Journal of Choice Modelling What determines student satisfaction with university subjects? A choice-based approach. Journal of Choice Modelling, $1-14$.

https://doi.org/10.1016/j.jocm.2015.10. 001

Khosravi, A. A., Poushaneh, K., Roozegar, A., \& Sohrabifard, N. (2013). Determination of Factors Affecting Student Satisfaction of Islamic Azad University. Procedia - Social and Behavioral Sciences, 84, 579-583. https://doi.org/10.1016/j.sbspro.2013.0 6.607

Kyoung, H., \& Knight, D. B. (2016). Gender Differences in Learning Outcomes from the College Experiences of Engineering Students. Journal OfEngineering Education, 105(3). https://doi.org/10.1002/jee.20125

Lenton, P. (2015). Economics of Education Review Determining student satisfaction: An economic analysis of the National Student Survey. Economics of Education Review, 47, 118-127. https://doi.org/10.1016/j.econedurev.20 15.05.001

Li, I. W., \& Carroll, D. R. (2017). Factors Influencing University Student Satisfaction, Dropout and Academic Performance. National Centre for 
Rais Hidayat Instrumen Kepuasan Mahasiswa Universitas Swasta Dengan Menggunakan ... | Rais Hidayat, dkk.

Student Equity in Higher Education (NCSEHE), Perth: Curtin University, $1-56$.

Linacre, J. M. (2010). Predicting Responses from Rasch Measures. JOURNAL OF APPLIED MEASUREMENT, 11(1), 110.

Moro-egido, A. I., \& Panadés, J. (2014). An Analysis of Student Satisfaction: FullTime vs . Part-Time Students. Social Indicators Research, (April 2010). https://doi.org/10.1007/s11205-0099482-1

Muhammad, N., Kakakhel, S. J., Baloch, Q. B., \& Ali, F. (2018). Review of Public Administration and Management Service Quality the Road Ahead for Student ' s Satisfaction. Review of Public Administration and Management, $\quad 6(2), \quad 2-7$. https://doi.org/10.4172/23157844.1000250

NGUYEN THANH DONG, D. N. F. S. (2014). Applying the Rasch Model to Investigate Singapore Principals , Instructional Leadership Practices. Leading \& Managing, 20(2), 1-26.

Nurunnabi, M., \& Abdelhadi, A. (2019). Data in Brief Student satisfaction in the Russell Group and Non-Russell Group Universities in UK. Data in Brief, 22, 76-82.

https://doi.org/10.1016/j.dib.2018.11.1 24

Oriade, A., \& Scho, P. (2019). Journal of Destination Marketing \& Management An examination of the role of service quality and perceived value in visitor attraction experience. Journal of Destination Marketing \& Management, 11(May 2018), 1-9. https://doi.org/10.1016/j.jdmm.2018.10 .002
Papachristos, N. M., Vrellis, I., Natsis, A., \& Mikropoulos, T. A. (2014). The role of environment design in an educational Multi-User Virtual Environment. British Journal of Educational Technology, 45(4), 636-646. https://doi.org/10.1111/bjet.12056

Siming, L., Gao, J., \& Xu, D. (2015). Factors Leading to Students ' Satisfaction in the Higher Learning Institutions. Journal of Education and Practice, 6(31), 114118.

Stef van Buuren, D. J. D. W. (2015). Measuring Psychosocial Impact of CBRN Incidents by the Rasch Model. JOURNAL OF APPLIED MEASUREMENT, 16(3).

Takaki, J., Taniguchi, T., \& Fujii, Y. (2014). Reliability, Validity, and Significance of Assessment of Sense of Contribution in the Workplace. IInternational Journal of Environmental Research and Public Health, 11, 1594-1604. https://doi.org/10.3390/ijerph11020159 4

Tesio, Il. (2003). Measuring Behaviours And Perceptions : Rasch Analysis As A Tool For Rehabilitation Research. J Rehabil Med, 35, 105-115.

Topala, I., \& Tomozii, S. (2014). Learning satisfaction: validity and reliability testing for students , learning satisfaction questionnaire ( SLSQ ). Procedia - Social and Behavioral Sciences, $\quad 128, \quad 380-386$. https://doi.org/10.1016/j.sbspro.2014.0 3.175

Triventi, M., \& Trivellato, P. (2012). Does Graduating from a Private University Make a Difference? Evidence from Italy. European Journal of Education, 47(2), 260-276. 
Williams, S. (2012). Open-source learning management systems: a predictive model for higher education. Journal of Computer Assisted Learning, 114-125. https://doi.org/10.1111/j.13652729.2011.00422.x

Wu, M., \& Adams, R. (2007). Applying The Rasch Model To Psycho-Social Measurement A Practical Approach. Melbourne.: Educational Measurement Solutions.
Yanikoski, R. (2004). Leadership Perspectives on the Role of Character Development in Higher Education. NEW DIRECTIONS FOR INSTITUTIONAL RESEARCH, (122), 7-23.

Zile-Tamsen, C. Van. (2017). Using Rasch Analysis to Inform Rating Scale. Research in Higher Education. https://doi.org/10.1007/s11162-0179448-0 